\title{
RANCANGAN FASILITAS KERJA PADA PROSES PERAKITAN CONTROLLER DI PT. MULTITANAKA SURYATAMA BERDASARKAN PRINSIP ERGONOMI
}

\author{
Lamto Widodo, Wayan Sukania dan Kevin Yota \\ Program Studi Teknik Industri, Universitas Tarumanagara Jakarta \\ e-mail: lamtow@ft.untar.ac.id
}

\begin{abstract}
ABSTRAK
PT Multitanaka Suryatama adalah sebuah perusahaan yang bergerak dalam bidang manufaktur plastik. Salah satu proses yang dilakukan di perusahaan ini adalah proses perakitan controller. Berdasarkan analisis kuisioner Nordic Body Map (NBM), proses ini dikerjakan dengan posisi kerja yang menyebabkan keluhan fisik operator. Posisi kerja pada proses ini memiliki tingkat risiko musculoskeletal yang tertinggi berdasarkan analisis Rapid Entire Body Assesment (REBA) yaitu memiliki skor 11. Analisis dengan menggunakan peta tangan kanan dan kiri menunjukkan adanya kegiatan-kegiatan yang tidak efisien dan dapat dieliminasi seperti kegiatan mencari, menganggur, dan menjangkau. Tahap penelitian berikutnya adalah dilakukan analisis keluhan, harapan dan kebutuhan serta kuisioner perancangan fasilitas kerja. Berdasarkan hal tersebut, didapatkan 3 (tiga) buah alternatif desain yang kemudian dipilih dengan menggunakan metode Analytical Hierarchy Process. Alternatif yang terpilih disesuaikan dengan antropometri tubuh pekerja dan dilakukan simulasi dengan menggunakan perangkat lunak CATIA sehingga didapatkan nilai REBA adalah 3 (dapat diterima, risiko rendah). Kemudian hasil rancangan diujudkan dalam bentuk prototype dan dilakukan implementasi. Hasil implementasi menunjukkan keluhan fisik berkurang dari 17 bagian tubuh menjadi 2 bagian tubuh. Skor tertinggi REBA mengalami penurunan menjadi 2 sehingga tingkat risiko rendah. Kegiatan mencari, menganggur dan menjangkau dieliminasi sehingga terjadi penurunan waktu siklus untuk proses perakitan sebesar 14,43\%.
\end{abstract}

Kata Kunci: Ergonomi, NBM, REBA, Peta Tangan Kanan dan Tangan Kiri, AHP

\begin{abstract}
PT Multitanaka Suryatama is a company engaged in plastic manufacturing. One of the main processes carried out is the assembly of the controller. Based on the Nordic Body Map (NBM) questionnaire analysis, the work position in this activity caused several operator physical complaints. The work position in this process has the highest musculoskeletal risk level based on Rapid Entire Body Assessment (REBA) analysis, which has a score of 11. Analysis of right and left hand maps shows that there are activities that are inefficient, namely searching, unemployment, and reaching activities. The next stage of the research is to analyze complaints, expectations and needs, and design the work facilities. Based on this analysis, there were 3 (three) alternative designs which were then selected using the Analytical Hierarchy Process method. The chosen alternative was adjusted to the body anthropometry and carried out a simulation using CATIA software so that the REBA value was 3 (acceptable, low risk). Then a prototype was created from the results of the design selected and carried out implementation. Implementation shows physical complaints of body parts decreasing from 17 to 2. REBA's highest score has decreased to 2 so that the risk level is low. Activities such as searching, idle and reaching are eliminated so that the cycle time decreases for the assembly process by $14.43 \%$.
\end{abstract}

Keywords: Ergonomics, NBM, REBA, Right and Left Hand Maps, AHP

\section{PENDAHULUAN}

PT Multitanaka Suryatama merupakan sebuah perusahaan yang bergerak dalam bidang manufaktur khususnya dalam bidang injection plastik. Sebagian kegiatan yang ada pada perusahaan ini dilakukan dengan menggunakan mesin seperti mesin CNC milling, drilling, bubut dan gundrill. Salah satu proses produksi yang dilakukan secara manual adalah proses perakitan controller. Pekerjaan yang dilakukan secara manual dikhawartirkan akan mempengaruhi postur kerja karyawan serta kesehatan dan keselamatan kerja karyawan sehingga perlu dilakukan evaluasi kerja [1] Postur kerja yang tidak ergonomis akan menyebabkan tenaga kerja lebih cepat mengalami kelelahan dan secara tidak langsung memberikan tambahan beban kerja [2]. Saat ini para pekerja pada proses perakitan controller memiliki postur kerja yang tidak ergonomis. 
Posisi badan dan leher pekerja seringkali membungkuk sementara kaki pekerja terlipat dan tertekuk. Hal ini disebabkan karena tidak adanya fasilitas kerja berupa meja sehingga benda kerja diletakkan di atas pallet kayu dan para pekerja bekerja dengan menggunakan bangku kecil untuk duduk. Tidak adanya fasilitas kerja yang memadai menyebabkan sistem kerja yang tidak ergonomis yang akan mengakibatkan resiko terhadap aspek kenyamanan, keselamatan dan kesehatan kerja serta berakibat pada pencapaian produktivitas kerja [3].

Sikap kerja yang salah akan menyebabkan terjadinya masalah dan keluhan pada tubuh pekerja [4]. Kuisioner Nordic Body Map adalah kuisioner yang paling sering digunakan untuk mengidentifikasi keluhan yang awalnya dirancang untuk semua gangguan musculoskeletal terutama untuk nyeri pada punggung bagian bawah [5]. Nordic body map membagi tubuh menjadi 27 bagian untuk mempermudah identifikasi keluhan pada setiap bagian tubuh. Berdasarkan hasil kuisioner, pekerja mengalami keluhan pada bagian tubuh sakit pinggang bawah, sakit leher atas, sakit pinggang, sakit punggung, sakit betis kanan, sakit telapak kaki kiri, sakit pantat, sakit betis kiri, sakit telapak kaki kanan, sakit bahu kanan, sakit pergelangan tangan kanan, sakit tangan kanan, sakit lengan atas kanan, sakit leher bawah, sakit bahu kiri, sakit lengan atas kiri dan sakit lengan bawah kiri. Maka dari itu perlu dilakukan penelitian untuk mendapat rancangan fasilitas kerja untuk mengurangi keluhan dengan meminimalkan tingkat risiko mucculoskeletal pada pekerja.

Metode yang digunakan untuk mengukur tingkat risiko adalah metode Rapid Entire Body Analysis (REBA) yang dirancang untuk mengevaluasi suatu pekerjaan yang menyebabkan ketidaknyamanan anggota tubuh dalam bekerja. Dalam metode ini, segmensegmen tubuh dibagi menjadi dua grup, yaitu Grup A dan Grup B. Grup A terdiri dari punggung (batang tubuh), leher dan kaki. Sedangkan Grup B terdiri dari lengan atas, lengan bawah dan pergelangan tangan. Penentuan skor REBA, yang mengindikasikan level resiko dari postur kerja dimulai dengan penentuan skor A untuk postur-postur grup A ditambah dengan skor beban (load) dan skor B untuk postur postur grup B ditambah dengan skor coupling. Kedua skor tersebut (skor A dan B) digunakan untuk menentukan skor C. Skor REBA diperoleh dengan menambahkan skor aktivitas pada skor C [6], [7]. Skor cara penilaian REBA dapat dilihat pada Tabel 1.

Tabel 1. Tabel Level Risiko [8]

\begin{tabular}{|c|c|c|c|}
\hline $\begin{array}{c}\text { Skor } \\
\text { REBA }\end{array}$ & $\begin{array}{l}\text { Tingkat } \\
\text { Risiko }\end{array}$ & Level & Tindakan \\
\hline 1 & $\begin{array}{c}\text { Dapat } \\
\text { diabaikan }\end{array}$ & 0 & $\begin{array}{c}\text { Tidak } \\
\text { diperlukan }\end{array}$ \\
\hline $2-3$ & Rendah & 1 & $\begin{array}{l}\text { Mungkin } \\
\text { diperlukan }\end{array}$ \\
\hline $4-7$ & Cukup Tinggi & 2 & Diperlukan \\
\hline $8-10$ & Tinggi & 3 & $\begin{array}{l}\text { Diperlukan } \\
\text { segera }\end{array}$ \\
\hline $11-15$ & Sangat Tinggi & 4 & $\begin{array}{c}\text { Diperlukan } \\
\text { sekarang }\end{array}$ \\
\hline
\end{tabular}

Selain mengurangi tingkat risiko, fasilitas kerja yang dirancang harus dapat mempermudah pekerjaan dan mengurangi waktu baku. Oleh karena itu pengukuran waktu kerja dilakukan untuk mendapatkan waktu baku untuk proses perakitan. Pengukuran waktu adalah pekerjaan menggamati dan mencatat waktu kerja baik seitap elemen ataupun siklus [9]. Kegiatan pengukuran waktu dikatakan selesai bila data berdistribusi normal dan semua data diperoleh telah seragam dan jumlahnya telah memenuhi tingkat ketelitian dan tingkat keyakinan yang diinginkan. Selanjutnya adalah mengolah data untuk menghitung waktu baku dengan menghitung waktu normal terlebih dahulu. [10]

Analisis peta tangan kanan dan kiri juga digunakan untuk membantu mengetahui waktu dan tiap-tiap gerakan kerja agar dapat diketahui gerakan-gerakan yang sebenarnya tidak perlu dilakukan oleh operator atau yang biasa disebut gerakan-gerakan yang tidak efektif [11] Dengan mengetahui gerakan-gerakan ini, maka akan diupayakan perbaikan gerakan yang akan menghemat waktu atau fasilitas yang tersedia. Penghematan waktu dilakukan dengan menghilangkan atau mengurangi gerakangerakan yang tidak efektif [12]. Peta ini sangat baik untuk menganalisis suatu sistem kerja 
sehingga diperoleh: perbaikan tata letak peralatan, pola gerakan pekerja yang baik, dan urut-urutan pekerja yang baik [9].

Berdasarkan uraian diatas, tujuan penelitian adalah untuk mendapatkan rancangan fasilitas kerja untuk mengurangi tingkat risiko musculoskeletal dan mengurangi waktu baku. Penyusunan rancangan fasilitas kerja dilakukan berdasarkan analisis keluhan fisik yang dirasakan oleh pekerja, analisis peta tangan kanan dan kiri, serta kuisioner perancangan produk. Tahap penyusunan konsep dilakukan untuk mendapatkan beberapa alternatif rancangan dan kemudian dilakukan pemilihan konsep dengan menggunakan metode Analtical Hierarchy Process. AHP adalah teori pengukuran melalui perbandingan berpasangan yang bergantung pada penilaian para ahli untuk mendapatkan skala prioritas. Perbandingan dibuat dengan menggunakan skala penilaian absolut yang mewakili seberapa besar satu elemen mendominasi elemen lainnya sehubungan dengan atribut tertentu [13].

Hasil rancangan yang didapat dianalisis tingkat risikonya dengan melakukan simulasi dengan menggunakan perangkat lunak Catia. Simulasi dilakukan dengan menggunakan aplikasi Ergonomics Design \& Analysis sehinggga dapat menentukan posisi postur tubuh dari manikin yang telah dimodelkan [14].

\section{METODE PENELITIAN}

Penelitian dilakukan di PT Multitanaka Suryatama yang terletak di daerah Cikarang Pusat, Bekasi. Pada penelitian awal dilakukan wawancara awal kepada para pekerja dan dilakukan pengamatan langsung. Setelah melakukan itu dilakukan identifikasi masalah, perumusan masalah dan tujuan penelitian yang akan dilakukan. Selanjutnya dilakukan dokumentasi postur kerja, kuesioner umum, kuesioner Nordic body map, data aliran proses kerja dan data waktu produksi waktu melakukan perakitan controller. Kemudian dilakukan data kuesioner Nordic body map, pengolahan data REBA, data peta tangan kanan dan tangan kiri, dan data perhitungan waktu produksi. Yang kemudian dilakukan analisis untuk masing-masing data hasil pengolahan tersebut. Setekah itu dilakukan perancangan perbaikan dengan melakukan perancangan perbaikan dengan cara menganlisa keluhan, harapan, dan kebutuha, melakukan kuesioner perancangan dan melakukan perancangam produk, yang kemudian dilakukan penentuan alternatif dengan AHP. Lalu tahap terakhir sebelum melakukan implementasi perancangan, perlu dilakukannya analisis dengan menggunakan CATIA. Setelah barang jadi perlu dilakukannya analisis hasil ulang ergonomi pekerja, waktu baku, dan peta tangan kanan dan tangan kiri. Berikut merupakan diagram alir/flowchart dapat dilihat pada Gambar 1.

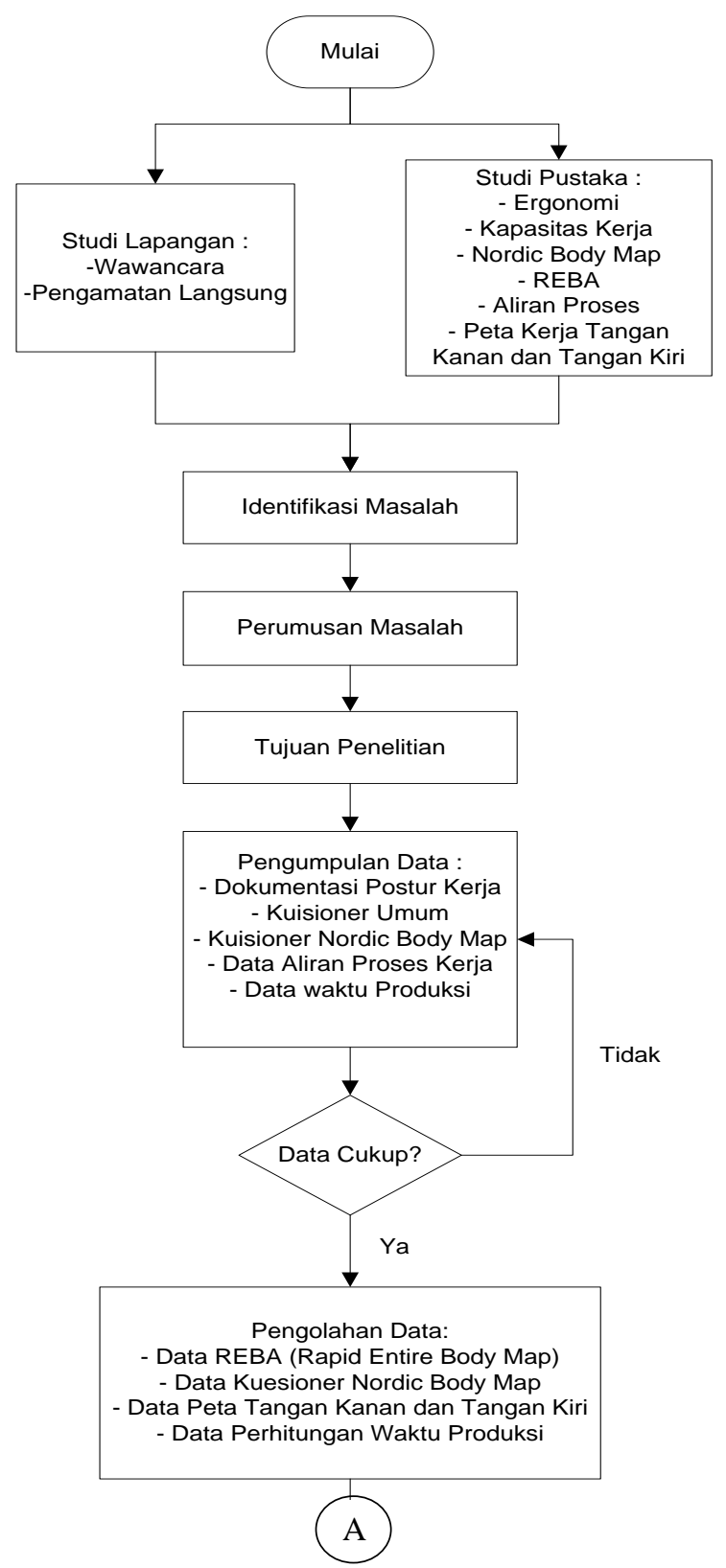

Gambar 1. Flowchart Penelitian 


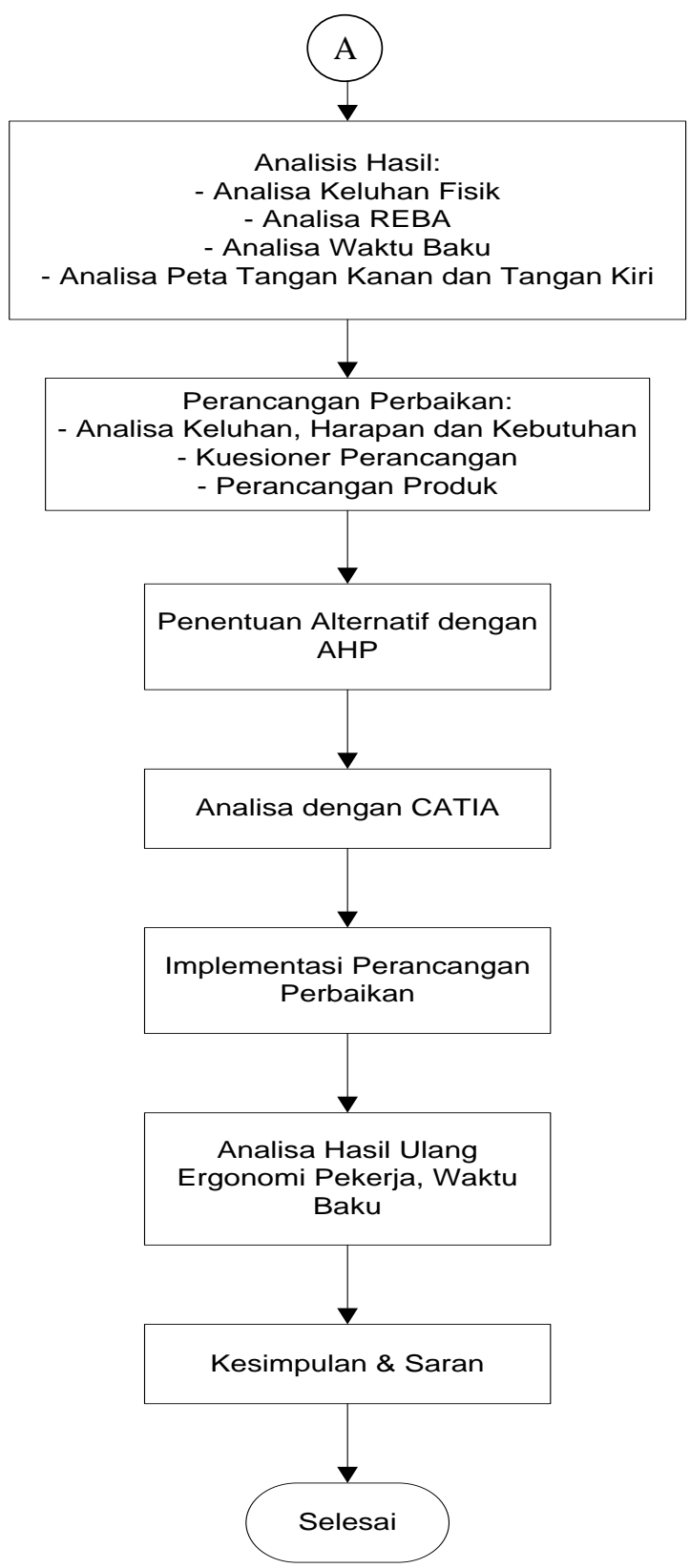

\section{PENGUMPULAN DAN PENGOLAHAN DATA}

Pada penelitian ini akan dilakukan pengumpulan data menggunakan data primer yaitu wawancara langsung kepada para pekerja di stasiun perakitan controller pada PT Multitanaka Suryatama yang terletak di Kawasan Greenland Industri. Kuisioner ini bertujuan untuk mengetahui identitas awal pekerja dan kebiasaan pekerja. Kuisioner umum dapat dilihat pada Tabel 2.

Selain itu juga dilakukan pengumpulan data kuesioner Nordic Body Map yang bertujuan untuk mengetahui bagian tubuh mana saja dari pekerja yang terasa sakit pada saat sebelum dan sesudah melakukan pekerjaan. Pengambilan data kuesioner ini juga dilakukan dengan metode wawancara langsung mengenai keluhan apa saja yang dialami oleh ketiga pekerja tersebut dengan diikuti juga pembagian kuesioner nordic body map.

Dari pengumpulan dan pengolahan data kuisioner Nordic Body Map yang kemudian di rank maka didapatkan keluhan-keluhan fisik yang dialami ketika melakukan pekerjaan saat ini. Berikut merupakan Tabel ranking keluhan fisik pekerja dan tingkat keluhan dapat dilihat pada Tabel 3.

Lanjutan Gambar 2. Flowchart Penelitian

Tabel 2. Kuisioner Umum

\begin{tabular}{cllll}
\hline No. & \multicolumn{1}{c}{ Keterangan } & \multicolumn{1}{c}{ Pekerja 1 } & \multicolumn{1}{c}{ Pekerja 2 } & \multicolumn{1}{c}{ Pekerja 3 } \\
\hline 1 & Nama & Endang Suhendar & Hadi Suprayitno & Odih Hendriatna \\
2 & Umur & 27 Tahun & 27 Tahun & 19 Tahun \\
3 & Tinggi & $174 \mathrm{Cm}$ & $170 \mathrm{Cm}$ & $163 \mathrm{Cm}$ \\
4 & Berat Badan & $63 \mathrm{Kg}$ & $51 \mathrm{Kg}$ & $50 \mathrm{Kg}$ \\
5 & Lama Bekerja & 4 Tahun & $5 \mathrm{Tahun}$ & $4 \mathrm{Tahun}$ \\
6 & Waktu Bekerja Per Hari & 8 Jam & 8 Jam & 8 Jam \\
7 & Status Pernikahan & Sudah Menikah & Sudah Menikah & Belum Menikah \\
8 & Merokok & Iya & Iya & Iya \\
\hline
\end{tabular}


Tabel 3. Ranking Keluhan Fisik Pekerja dan Tingkat Keluhan

\begin{tabular}{cccccc}
\hline \multirow{2}{*}{ No. } & \multirow{2}{*}{ Jenis Keluhan } & \multicolumn{4}{c}{ Tingkat Keluhan } \\
\cline { 3 - 6 } & & TS & AS & S & SS \\
\hline 8 & Sakit pinggang bawah & 0 & 0 & 1 & 2 \\
0 & Sakit leher atas & 0 & 0 & 2 & 1 \\
7 & Sakit pinggang & 0 & 0 & 2 & 1 \\
5 & Sakit punggung & 0 & 1 & 1 & 1 \\
23 & Sakit betis kanan & 0 & 0 & 2 & 1 \\
26 & Sakit telapak kaki kiri & 0 & 0 & 2 & 1 \\
9 & Sakit pantat & 0 & 0 & 3 & 0 \\
22 & Sakit betis kiri & 0 & 0 & 3 & 0 \\
27 & Sakit telapak kaki kanan & 0 & 0 & 3 & 0 \\
3 & Sakit bahu kanan & 0 & 1 & 2 & 0 \\
15 & Sakit pergelangan tangan kanan & 0 & 1 & 2 & 0 \\
17 & Sakit tangan kanan & 0 & 1 & 2 & 0 \\
6 & Sakit lengan atas kanan & 0 & 2 & 1 & 0 \\
1 & Sakit leher bawah & 2 & 1 & 0 & 0 \\
2 & Sakit bahu kiri & 2 & 1 & 0 & 0 \\
4 & Sakit lengan atas kiri & 2 & 1 & 0 & 0 \\
13 & Sakit lengan bawah kanan & 2 & 1 & 0 & 0 \\
\hline
\end{tabular}

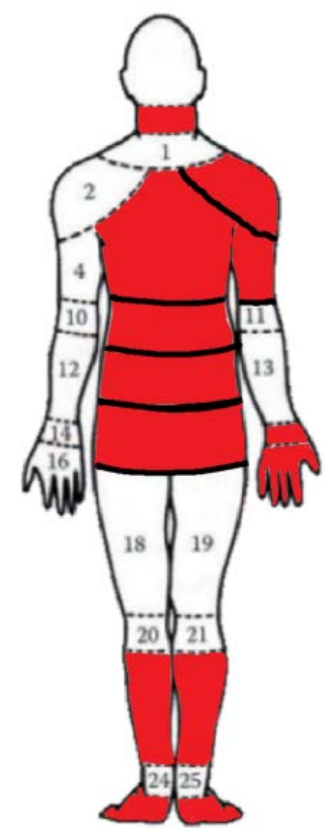

Catatan: TS = Tidak Sakit, AS = Agak Sakit, S = Sakit, SS = Sangat Sakit

Dari Tabel 3 diketahui bahwa keluhan fisik yang paling utama dirasakan pekerja pada bagian pinggang bawah, leher atas, pinggang, punggung, betis kanan, telapak kaki kiri dan lain sebagainnya. Maka dari itu dilakukan analisis dengan menggunakan metode REBA (Rapid Entire Body Assessment) untuk mengetahui tingkat risiko musculoskeletal pada proses ini, yang terdapat 5 tahapan yang harus dilakukan yaitu: pengambilan data postur pekerja dengan menggunakan bantuan foto postur tubuh, penentuan sudut-sudut dari bagian tubuh pekerja, menentukan berat benda yang diangkat oleh pekerja, coupling, dan aktifitas para pekerja. Kemudian pada masing-masing faktor tersebut juga mempunyai kategori skor, yang dilakukan penilaian skor akhir A, B dan yang terakhir $\mathrm{C}$, dan kemudian didapatkan nilai level tindakan yang harus dilakukan.

Setelah itu didapatkan hasil rekapitulasi REBA dari 5 kegiatan tersebut dengan NBM. Berikut merupakan hasil rekapitulasi REBA dengan NBM pada proses perakitan dapat dilihat pada Tabel 4.

Berdasarkan analisis dengan menggunakan metode REBA maka dapat disimpulkan bahwa proses perakitan controller mempunyai tingkat risiko musculoskeletal yang cukup tinggi dengan skor REBA tertinggi adalah 11 dan diperlukan tindakan segera. Maka dari itu perancangan fasilitas kerja diperlukan untuk mengurangi tingkat risiko.

Selain untuk mengurangi tingkat risiko musculoskeletal, penelitian ini juga bertujuan untuk mengurangi waktu baku dan mendapatkan sistem kerja terbaik. Maka dari itu dilakukan analisis dengan menggunakan peta tangan kanan dan tangan kiri agar pekerjaan yang tidak efisien dapat diidentifikasi dan diperbaiki. Berikut merupakan dua contoh peta tangan kanan dan tangan kiri pada pekerjaan pemasangan slop dan pekerjaan pemasangan tangan kanan dan tangan kiri pada pekerjaan pemasangan slop dan pekerjaan pemasangan fan dapat dilihat pada Tabel 5.

Posisi peralatan dan benda kerja juga akan dirancang ulang agar berada pada posisi yang mudah dijangkau sehingga dapat mempercepat waktu penyelesaian produk. Dengan menggunakan peta tangan kanan dan tangan kiri dapat dihitung waktu siklus untuk setiap pekerjaan pada perakitan controller. Setelah implementasi fasilitas kerja maka dapat dilakukan analisis ulang untuk membuktikan adanya pengurangan waktu siklus. Berikut merupakan hasil waktu tiap siklus dari peta tangan kanan dan tangan kiri pada Tabel 6. 
Tabel 4. Tabel Rekapitulasi REBA dengan NMD pada Proses Perakitan

\begin{tabular}{|c|c|c|c|c|c|}
\hline Kegiatan & Memotong Kabel & $\begin{array}{c}\text { Mengencangkan } \\
\text { Baut }\end{array}$ & $\begin{array}{l}\text { Memasukkan } \\
\text { Kabel ke } \\
\text { Konektor }\end{array}$ & $\begin{array}{c}\text { Merapihkan } \\
\text { Kabel }\end{array}$ & $\begin{array}{l}\text { Memasang } \\
\text { Fan }\end{array}$ \\
\hline $\begin{array}{l}\text { Gambar } \\
\text { Postur } \\
\text { Pekerja }\end{array}$ & & & & & \\
\hline $\begin{array}{c}\text { Skor Reba } \\
\text { Level Resiko } \\
\text { Tindakan } \\
\text { Perbaikan }\end{array}$ & $\begin{array}{c}5 \\
\text { Sedang } \\
\text { Diperlukan }\end{array}$ & $\begin{array}{c}10 \\
\text { Tinggi } \\
\text { Diperlukan } \\
\text { Segera }\end{array}$ & $\begin{array}{c}9 \\
\text { Tinggi } \\
\text { Diperlukan } \\
\text { Segera }\end{array}$ & $\begin{array}{c}9 \\
\text { Tinggi } \\
\text { Diperlukan } \\
\text { Segera }\end{array}$ & $\begin{array}{c}11 \\
\text { Sangat Tinggi } \\
\text { Diperlukan } \\
\text { Segera }\end{array}$ \\
\hline $\begin{array}{l}\text { Nordic Body } \\
\text { Map (NBM) }\end{array}$ & \multicolumn{5}{|c|}{$\begin{array}{l}\text { Sakit pada: Pinggang bawah, leher atas, pinggang, punggung, betis kanan, telapak kaki kiri, pantat, } \\
\text { betis kiri, telapak kaki kanan, bahu kanan, pergelangan tangan kanan, tangan kanan, lengan atas } \\
\text { kanan, leher bawah, bahu kiri, lengan atas kiri, lengan bawah kanan. }\end{array}$} \\
\hline
\end{tabular}

Tabel 5. Peta Tangan Kanan dan Tangan Kiri pada Pekerjaan Pemasangan Slop dan Pekerjaan Pemasangan Fan
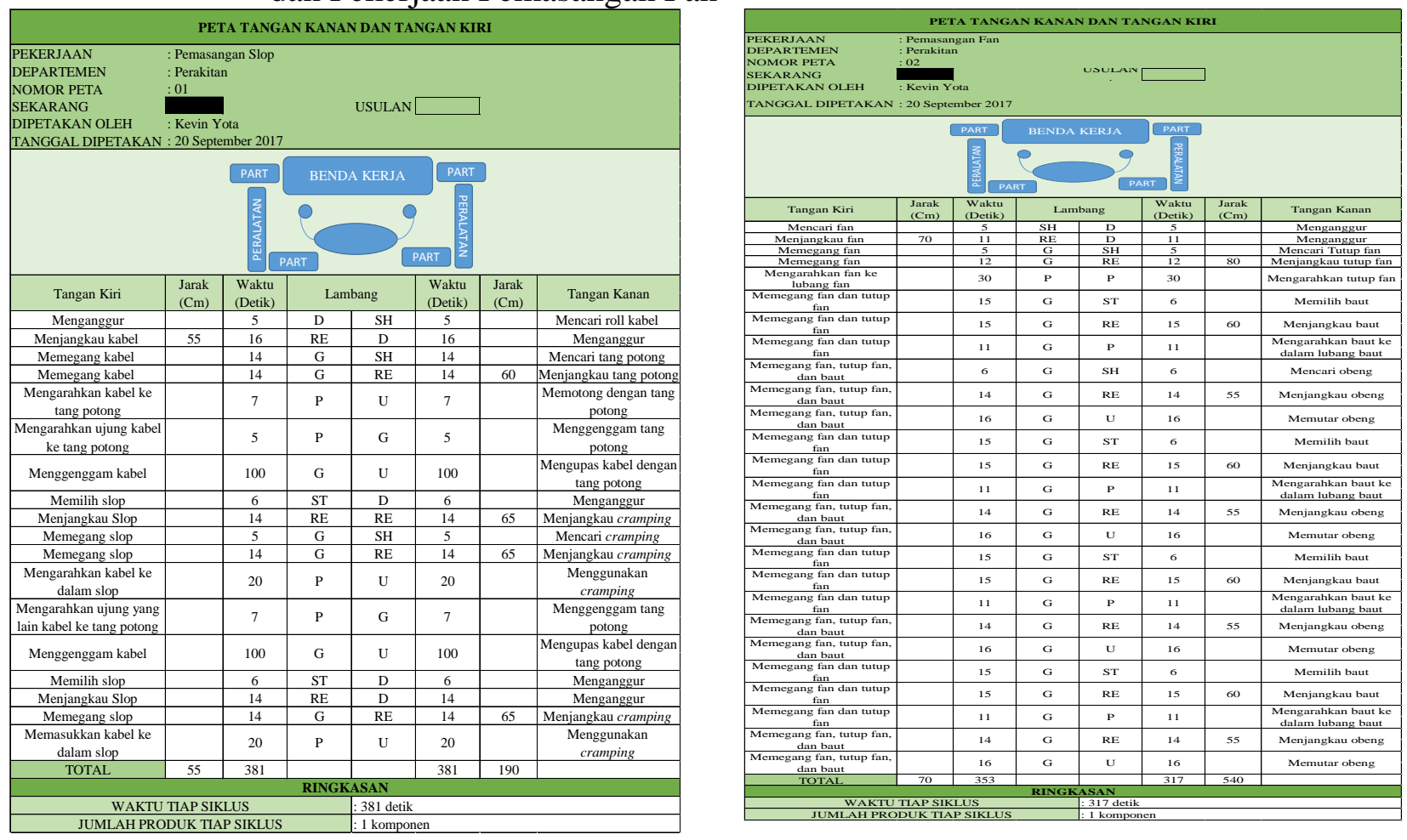

Tabel 6. Hasil Waktu Tiap Siklus dari Peta Tangan Kanan dan Tangan Kiri

\begin{tabular}{clcc}
\hline No. Peta & \multicolumn{1}{c}{ Pekerjaan } & Waktu Tiap Siklus & $\begin{array}{c}\text { Jumlah Produksi } \\
\text { Tiap Siklus }\end{array}$ \\
\hline 01 & Pemasangan Schon & $381 \mathrm{detik}$ & 1 Komponen \\
02 & Pemasangan Fan & $317 \mathrm{detik}$ & 1 Komponen \\
03 & Pemasangan Heatsink & $214 \mathrm{detik}$ & 1 Komponen \\
04 & Pemasangan Temprature Card Controller & $125 \mathrm{detik}$ & 1 Komponen \\
05 & Pemasangan Switch On/Off & $160 \mathrm{detik}$ & 1 Komponen \\
06 & Pemasangan Magnetic Circuit Breaker & $108 \mathrm{detik}$ & 1 Komponen \\
07 & Pemasangan Solid State Relay & $130 \mathrm{detik}$ & 1 Komponen \\
08 & Pemasangan Connector Plug & 216 detik & 1 Komponen \\
09 & Pemasangan Rumah Fuse & 48 detik & 1 Komponen \\
10 & Pemasangan Terminal & 45 detik & 1 Komponen \\
\hline
\end{tabular}


Setelah melakukan penganalisis pekerjaan peta tangan kanan dan tangan kiri, maka dilakukan pengolahan data waktu perakitan yang didapatkan dari perusahaan dari Januari 2017 sampai Agustus 2017 dan terdapat 54 perakitan. Langkah selanjutnya melakukan pengujian data yang dilakukan adalah uji kenormalan data, uji keseragaman data, dan uji kecukupan data. Pada uji kenormalan data yang diperoleh dengan menggunakan software SPSS dengan Kolmogorov-Smirnov, dihasilkan bahwa data berdistribusi normal, dengan nilai P-Value > 0.05. Untuk uji keseragaman didapatkan hasil akhir dari grafik bahwa rata-rata dari tiap subgroup berada diantara batas atas dan batas bawah, maka data hasil pengukuran waktu perakitan controller yang dilakukan bersifat seragam dan dalam batas kendali. Kemudian pada uji kecukupan data didapatkan nilai $\mathrm{N}^{\prime}$ sebesar 7,45, dimana Nilai $\mathrm{N}^{\prime}<\mathrm{N}$ maka dapat disimpulkan bahwa pengambilan data proses perakitan controller yang diambil sudah cukup.

Setelah dilakukan dan dibuktikan data yang didapatkan normal, seragam dan cukup, maka dapat dilakukan perhitungan waktu baku dengan melakukan perhitungan waktu siklus dan waktu normal terlebih dahulu. Tabel perhitungan waktu baku dapat dilihat pada Tabel 7.

Dari Tabel 7 didapatkan waktu baku dari proses perakitan controller pada PT Multitanaka Suryatama adalah 15,69 Jam.

\section{ANALISIS DATA DAN PERANCANGAN}

Berdasarkan analisis keluhan fisik pekerja diperoleh dari pengumpulan dan pengolahan data kuisioner Nordic Body Map, maka didapatkan 11 keluhan fisik tertinggi yang dialami oleh pekerja pada proses perakitan controller. Berikut ini merupakan rincian analisis keluhan yang dialami pada bagian tubuh pekerja yang dapat dilihat pada Tabel 8 .

Keluhan-keluhan tersebut dianalisis dan diidentifikasi penyebab keluhannya dengan cara wawancara langsung pada 3 orang pekerja sehingga didapatkan penyebab-penyebab keluhan tersebut. Berikut penjabaran keluhan, harapan serta kebutuhan desain fasilitas kerja dapat dilihat pada Tabel 9.

Tabel 7. Perhitungan Waktu Baku

\begin{tabular}{ccccc}
\hline Langkah & Simbol & Rumus & Perhitungan & Hasil \\
\hline Waktu Siklus & $W_{s}$ & $W_{s}=\frac{\sum x_{i}}{N}$ & $W_{s}=\frac{73,61}{6}$ & 12,27 Jam/Produk \\
& & $W_{n}=W_{s} x p$ & $W_{n}=12,27 x 0,92$ & $11,29 \mathrm{Jam}$ \\
Waktu Normal & $W_{n}$ & $W_{b}=W_{n}(1+L)$ & $W_{b}=11,29(1+0.39)$ & $15,69 \mathrm{Jam}$ \\
Waktu Baku & $W_{b}$ &
\end{tabular}

Tabel 8. Analisis Keluhan Fisik dan Penyebabnya

\begin{tabular}{|c|c|c|}
\hline No. & $\begin{array}{c}\text { Urutan } \\
\text { Keluhan Fisik }\end{array}$ & Analisis Penyebab Keluhan \\
\hline 1. & Sakit leher atas & $\begin{array}{l}\text { Keluhan pada bagian leher atas dikarenakan pekerja melakukan pekerjaannya dengan } \\
\text { keadaan menunduk yang dilakukan dalam jangka waktu yang cukup lama pada saat proses } \\
\text { perakitan, dimana dapat dibuktikan oleh postur REBA yang buruk. }\end{array}$ \\
\hline 2. & $\begin{array}{l}\text { Sakit bahu } \\
\text { kanan }\end{array}$ & $\begin{array}{l}\text { Pekerja berada pada posisi membungkuk pada saat melakukan proses perakitan dalam } \\
\text { waktu yang lama menyebabkan bahu berada pada posisi yang tidak benar dan kemudian } \\
\text { tangan kanan harus melakukan kegiatan menjangkau yang berulang dan jauh, yang } \\
\text { kemudian membuat bahu lebih cepat lelah, dibuktikan oleh postur REBA yang buruk. }\end{array}$ \\
\hline 3. & $\begin{array}{c}\text { Sakit } \\
\text { punggung }\end{array}$ & $\begin{array}{l}\text { Stasiun kerja proses perakitan yang mempunyai posisi terlalu rendah dan tidak adanya kursi } \\
\text { yang sesuai dengan tinggi yang seharusnya menyebabkan pekerja menjadi membungkuk } \\
\text { dalam jangka waktu yang cukup lama dan menyebabkan pinggang tertarik, dibuktikan oleh } \\
\text { postur REBA yang buruk. }\end{array}$ \\
\hline 4. & $\begin{array}{c}\text { Sakit lengan } \\
\text { atas kanan }\end{array}$ & $\begin{array}{l}\text { Pada keluhan ini disebabkan oleh pekerja melakukan banyak kegiatan yang membuat } \\
\text { lengan atas kanan menopang terlalu berat karena posisi kerja yang berada dibawah dan } \\
\text { diperlukan jangkauan-jangkauan yang jauh dan pekerjaan yang berulang-ulang, seperti } \\
\text { ngebaut, motong kabel, mengupas kabel, dan lain-lain, dibuktikan oleh postur REBA yang } \\
\text { buruk. }\end{array}$ \\
\hline
\end{tabular}


Tabel 8. Analisis Keluhan Fisik dan Penyebabnya

\begin{tabular}{|c|c|c|}
\hline No. & $\begin{array}{c}\text { Urutan } \\
\text { Keluhan Fisik }\end{array}$ & Analisis Penyebab Keluhan \\
\hline 5. & Sakit pinggang & $\begin{array}{l}\text { Pada keluhan ini disebabkan akan posisi tubuh pekerja yang melakukan banyak macam } \\
\text { posisi yang tidak sesuai dengan cara membungkuk dan jongkok yang dalam waktu yang } \\
\text { lama dan posisi yang tidak benar sehingga menyebabkan rasa sakit pada pinggang pekerja, } \\
\text { dibuktikan oleh postur REBA yang buruk. }\end{array}$ \\
\hline 6. & $\begin{array}{l}\text { Sakit pinggang } \\
\text { bawah }\end{array}$ & $\begin{array}{l}\text { Pada keluhan ini disebabkan akan posisi duduk yang terlalu rendah yang menyebabkan } \\
\text { beban pinggang yang harus menahan punggung yang harus membungkuk terus menerus dan } \\
\text { juga harus menahan kaki yang tertekuk selama pekerja duduk dibawah, dibuktikan oleh } \\
\text { postur REBA yang buruk. }\end{array}$ \\
\hline 7. & Sakit pantat & $\begin{array}{l}\text { Keluahan pada bagian pantat diakibatkan akan posisi duduk yang kurang nyaman dan } \\
\text { tempat duduk yang memposisikan pekerja seperti melakukan jongkok, dimana kursi yang } \\
\text { dipakai para pekerja sangat rendah dan membuat kaki tertekuk, dibuktikan oleh postur } \\
\text { REBA yang buruk. }\end{array}$ \\
\hline 8. & $\begin{array}{l}\text { Sakit } \\
\text { pergelangan } \\
\text { tangan kanan }\end{array}$ & $\begin{array}{l}\text { Sakit pada pergelangan tangan kanan diakibatkan karena kerja tangan kanan yang banyak } \\
\text { dengan melakukan kegiatan memutar obeng dimana posisi-posisi tersebut tidak didukung } \\
\text { dengan posisi jarak yang dekat dan mudah dijangkau, sehingga pergelangan tangan harus } \\
\text { menahan beban yang lebih dari pada yang seharusnya, dibuktikan oleh postur REBA yang } \\
\text { buruk. }\end{array}$ \\
\hline 9. & $\begin{array}{c}\text { Sakit tangan } \\
\text { kanan }\end{array}$ & $\begin{array}{l}\text { Sakit pada tangan kanan disebabkan tangan kanan melakukan proses memutar baut, } \\
\text { memotong kabel dan mengupas kabel yang diperlukan daya cengkaram, dibuktikan oleh } \\
\text { postur REBA yang buruk. }\end{array}$ \\
\hline 10. & $\begin{array}{c}\text { Sakit betis kiri } \\
\text { dan kanan }\end{array}$ & $\begin{array}{l}\text { Keluhan sakit ini terjadi karena proses duduk yang berada dibawah dan kaki tertekuk terlalu } \\
\text { lama, yang menyebabkan peredaran darah yang tidak jalan secara semestinya, dibuktikan } \\
\text { oleh postur REBA yang buruk. }\end{array}$ \\
\hline 11. & $\begin{array}{l}\text { Sakit telapak } \\
\text { kaki kiri dan } \\
\quad \text { kanan }\end{array}$ & $\begin{array}{l}\text { Pada saat proses perakitan pekerja mempunyai kursi yang terlalu pendek yang } \\
\text { menyebabkan kaki pekerja tertekuk terlalu lama yang mana menyebabkan peredaran darah } \\
\text { pada kaki tidak berjalan dengan baik dan juga menopang sebgaian dari berat badan, } \\
\text { dibuktikan oleh postur REBA yang buruk. }\end{array}$ \\
\hline
\end{tabular}

Tabel 9. Analisis Keluhan, Harapan, Kebutuhan dan Desain Alat

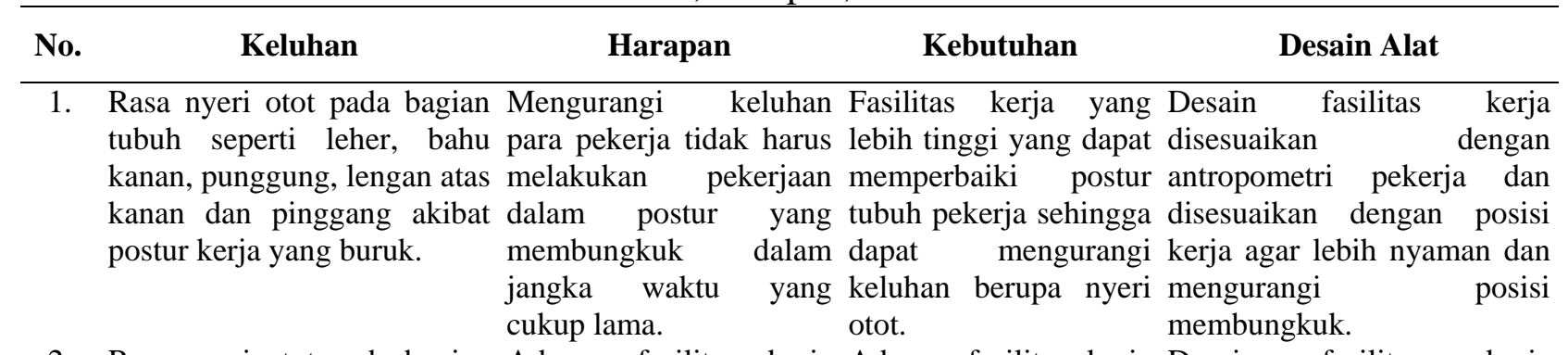

2. Rasa nyeri otot pada bagian Adanya fasilitas kerja Adanya fasilitas kerja Desain fasilitas kerja tubuh seperti pinggang, untuk membantu yang membantu disesuaikan dengan pinggang bawah, pantat, menopang berat tubuh menopang berat tubuh antropometri pekerja agar betis dan telapak kaki akibat yang mempunyai yang cukup tinggi lebih nyaman dan keluhan postur duduk saat kerja yang ketinggian yang cukup sehingga pekerja tidak berkurang. terlalu pendek seperti posisi sehingga tidak seperti harus bekerja duduk jongkok. jongkok. seperti dalam posisi jongkok.

3. Rasa nyeri otot pada bagian Mengurangi keluhan Penataan fasilitas kerja Desain fasilitas kerja tubuh seperti lengan atas para pekerja dengan dengan mengatur dan disesuaikan dengan jarak kanan, pergelangan kanan, mengurangi jarak melakukan perhitungan jangkauan tangan yang dan tangan kanan akibat jangkauan yang jarak yang optimal berdasarkan hitungan postur duduk saat kerja yang dilakukan berulang- agar tidak terjadinya antropometri pekerja agar terlalu jauh menjangkau ulang dalam waktu yang jangkauan tangan yang lebih nyaman dan keluhan untuk melakukan proses lama terhadap proses terlalu jauh. berkurang. perakitan. perakitan yang jauh. 
Lanjutan Tabel 9. Analisis Keluhan, Harapan, Kebutuhan dan Desain Alat

\begin{tabular}{|c|c|c|c|c|}
\hline No. & Keluhan & Harapan & Kebutuhan & Desain Alat \\
\hline 4. & $\begin{array}{l}\text { Tidak ada tempat khusus } \\
\text { untuk meletakkan peralatan, } \\
\text { sehingga terdapat kesulitan } \\
\text { dalam mencari peralatan } \\
\text { yang mau dipakai. }\end{array}$ & $\begin{array}{lr}\begin{array}{l}\text { Mengurangi } \\
\text { akan tidak keluhan }\end{array} \\
\text { tempat khusus untuk } \\
\text { meletakkan peralatan, } \\
\text { sehingga rapat } \\
\text { memudahkan dalam } \\
\text { mencari peralatan yang } \\
\text { mau dipakai. }\end{array}$ & $\begin{array}{l}\text { Dibutuhkan } \\
\text { penambahan tempat } \\
\text { fasilitas kerja untuk } \\
\text { menaruh ran } \\
\text { menyimpan peralatan. }\end{array}$ & $\begin{array}{l}\text { Desain fasilitas } \\
\text { disesuaikan dengan ukuran- } \\
\text { ukuran dari peralatan untuk } \\
\text { perakitan controller dan } \\
\text { mempunyai jarak yang } \\
\text { mudah dijangkau. }\end{array}$ \\
\hline 5. & $\begin{array}{l}\text { Keluhan tidak adanya tempat } \\
\text { untuk masing-masing } \\
\text { komponen dari controller, } \\
\text { dimana pada saat merakit } \\
\text { terjadinya kesulitan dan } \\
\text { dibutuhkan waktu untuk } \\
\text { menemukan komponen } \\
\text { tersebut. }\end{array}$ & $\begin{array}{l}\text { Adanya tempat untuk } \\
\text { masing-masing } \\
\text { komponen pada } \\
\text { controller untuk } \\
\text { memudahkan pekerja } \\
\text { untuk mencari dan } \\
\text { mengurangi waktu untuk } \\
\text { menemukan komponen } \\
\text { tersebut. }\end{array}$ & $\begin{array}{l}\text { Dibutuhkan } \\
\text { penambahan tempat } \\
\text { fasilitas kerja untuk } \\
\text { menaruh } \\
\text { menyimpan dan } \\
\text { komponen-komponen } \\
\text { pada perakitan } \\
\text { controller }\end{array}$ & $\begin{array}{l}\text { Desain fasilitas kerja } \\
\text { disesuaikan dengan ukuran- } \\
\text { ukuran dari komponen- } \\
\text { komponen untuk perakitan } \\
\text { controller dan mempunyai } \\
\text { jarak yang mudah dijangkau. }\end{array}$ \\
\hline
\end{tabular}

Berikutnya dilakukan analisis terhadap karakteristik apa saja yang dibutuhkan untuk merancang fasilitas kerja berupa meja kerja dan alternatif apa saja yang dapat diperoleh dari masing-masing karakteristik. Perolehan alternative didapatkan dengan membagikan kuisioner tertutup. Hasil alternatif yang didapat untuk masing-masing karakteristik dapat dilihat pada Tabel 10.

Dari berbagai alternatif-alternatif dari karakteristik pada masing-masing desain dapat dibuat tabel tabulasi alternatif perancangan. Tabel tabulasi alternatif perancangan dapat dilihat pada Tabel 11.

Tabel 10. Tabel Karakteristik dan Alternatif untuk Meja

\begin{tabular}{clc}
\hline No. & \multicolumn{1}{c}{ Karakteristik } & Alternatif Perolehan \\
\hline 1. & Bentuk Meja & Persegi Panjang; Persegi \\
2. & Mekanisme & Automatic; Manual \\
3. & Permukaan Diputar & Dapat Diputar; Tidak Dapat Diputar \\
4. & Bahan Permukaan Meja & Besi; Kayu \\
5. & Bahan Utama Tempat Roll Kabel & Besi; Kayu \\
6. & Bahan Utama Tempat Perkakas dan Komponen & Besi; Kayu \\
7. & Bahan Utama Alat Gantung Perkakas & Besi; Kayu \\
8. & Mempunyai Roda & Memakai; Tidak Memakai \\
\hline
\end{tabular}

Tabel 11. Tabulasi Alternatif Perancangan

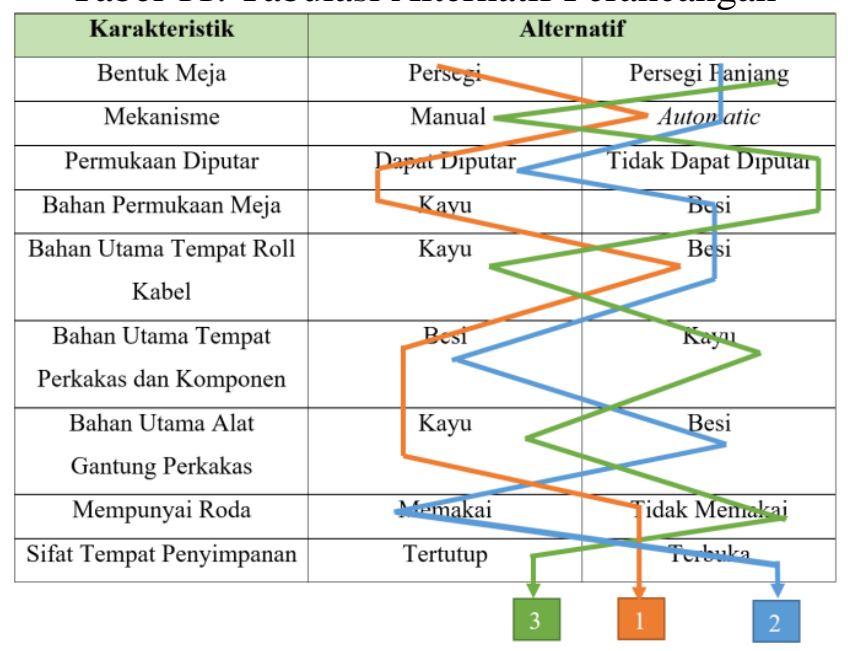


Tabel 12. Desain Alternatif untuk Proses Perakitan Controller

\begin{tabular}{|c|c|c|}
\hline Alternatif & Gambar & Keterangan \\
\hline 1 & & $\begin{array}{l}\text { Meja kerja yang berbentuk persegi, terbuat dari kayu dan pada permukaan } \\
\text { meja kerja terdapat tempat penyimpanan baut dan terdapat bagian yang } \\
\text { bisa diputar. Diatas meja juga terdapat alat untuk menggantung alat } \\
\text { perkakas. Pada samping kanan meja kerja terdapat rak yang dapat ditarik } \\
\text { untuk menyimpan alat-alat perkakas, komponen-komponen untuk merakit } \\
\text { controller dan terdapat tempat untuk roll kabel. Untuk meja dapat diatur } \\
\text { ketinggiannya secara otomatis menggunakan injekan kaki. Keputusan } \\
\text { pemilihan alternatif-alternatif tersebut berasal dari karakteristik yang } \\
\text { sudah ada untuk mendesain fasilitas kerja yang berupa meja. }\end{array}$ \\
\hline 2 & & $\begin{array}{l}\text { Meja kerja yang berbentuk persegi panjang, terbuat dari besi dan pada } \\
\text { permukaan meja kerja terdapat tempat penyimpanan baut yang tertanam } \\
\text { di dalam meja dan terdapat bagian yang bisa diputar. Diatas meja juga } \\
\text { terdapat alat untuk menggantung alat perkakas. Pada samping kanan dan } \\
\text { kiri meja kerja terdapat rak yang dapat ditarik untuk menyimpan alat-alat } \\
\text { perkakas, komponen-komponen untuk merakit controller dan terdapat } \\
\text { tempat untuk roll kabel. Untuk meja dapat diatur ketinggiannya secara } \\
\text { otomatis menggunakan injekan kaki. Keputusan pemilihan alternatif- } \\
\text { alternatif tersebut berasal dari karakteristik yang sudah ada untuk } \\
\text { mendesain fasilitas kerja yang berupa meja. }\end{array}$ \\
\hline 3 & & $\begin{array}{l}\text { Meja kerja yang berbentuk persegi panjang, terbuat dari besi dan pada } \\
\text { permukaan meja kerja terdapat tempat penyimpanan baut dan tidak } \\
\text { terdapat bagian yang bisa diputar. Pada samping kanan di permukaan } \\
\text { meja kerja terdapat rak terdapat } 3 \text { laci yang dapat ditarik untuk } \\
\text { menyimpan alat-alat perkakas dan komponen-komponen untuk merakit } \\
\text { controller. Pada sisi lain meja terdapat alat gantung untuk menggantung } \\
\text { roll-roll kabel. Untuk meja dapat diatur ketinggiannya secara manual atau } \\
\text { pompa. Keputusan pemilihan alternatif-alternatif tersebut berasal dari } \\
\text { karakteristik yang sudah ada untuk mendesain fasilitas kerja yang berupa } \\
\text { meja. }\end{array}$ \\
\hline
\end{tabular}

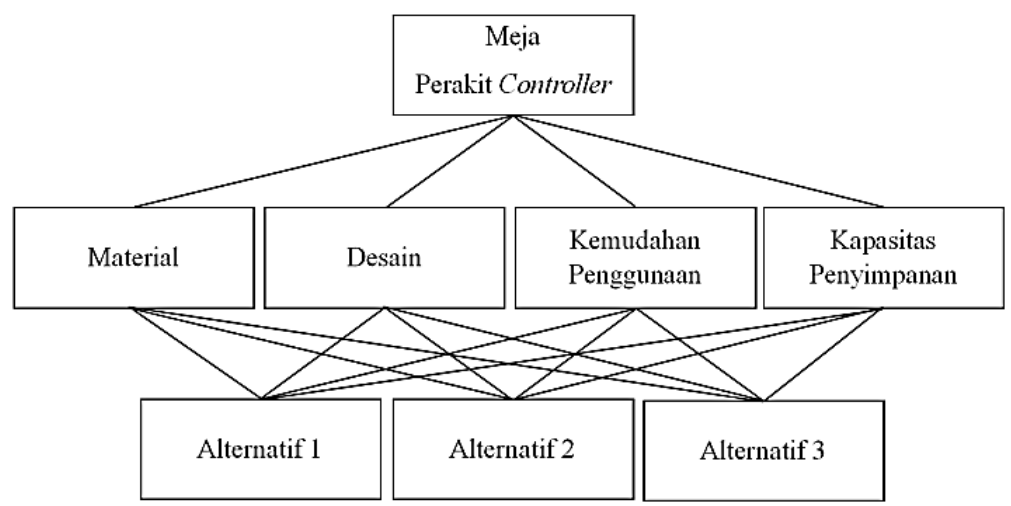

Gambar 3. Struktur Hirarki AHP Fasilitas Kerja pada Proses Perakitan Controller

Setelah mengetahui alternatif yang diinginkan oleh konsumen untuk setiap karakteristik maka dilanjutkan dengan melakukan perancangan fasilitas kerja. Tabel alternatif desain yang dirancang untuk proses perakitan controller dapat dilihat pada Tabel 12.

Setelah menemukan tiga alternatif konsep, dilakukan pemilihan konsep dengan menggunakan metode Analytical Hierarcy Process (AHP) untuk memilih konsep terbaik dari alternatif-alternatif yang terdapat beberapa kriteria yang dipunyai masing-masing alternatif. Pada AHP akan mudah dipahami, karena digambarkan secara grafis. Pada penggunaan AHP dengan struktur hirarki yang dimulai dari tujuan utama yaitu perancangan fasilitas kerja berupa meja perakit controller kemudian tingkat berikutnya berupa tujuan-tujuan dan tingkat yang terakhir yaitu alternatif-alternatif fasilitas kerja. Gambar struktur hirarki fasilitas 
kerja pada proses perakitan controller dapat dilihat pada Gambar 2.

Pada tahap selanjutnya dibuat kuisioner pemilihan konsep yang diberikan kepada 6 responden yaitu 3 orang operator, kepala pabrik, direktur, dan expert. Setelah didapatkan hasil kuesioner maka dibuat bentuk matriks perbandingan berpasangan, mencari nilai geometri untuk perbandingan kriteria dan perbandingan alternatif untuk setiap kriteria, iterasi hingga selisih nilai normalisasi lebih kecil dari 0,000010 dan kemudian menghitung composite weight. Perhitungan composite weight dapat dilihat pada Tabel 13.
Dari Tabel 13 didapatkan hasil composite weight yang tertinggi adalah alternatif 2 dengan nilai 0.6224 atau sebesar 62,24\%. Maka alternatif yang akan dirancang dan diimplementasikan untuk memperbaiki posisi kerja pada proses perakitakan controller adalah alternatif 2.

Alternatif yang sudah terpilih dilakukan perancangan dan didapatkan desain dimensi meja yang ergonomis untuk memperbaiki posisi kerja pada proses perakitan controller. Untuk dimensi dan gambar meja perakitan controller yang digunakan dapat dilihat pada Tabel 14.

Tabel 13. Perhitungan Composite Weight

\begin{tabular}{|c|c|c|c|c|c|c|c|}
\hline \multirow[t]{2}{*}{ Elemen } & \multirow{2}{*}{ Bobot } & \multicolumn{3}{|c|}{ Bobot Alternatif } & \multicolumn{3}{|c|}{ Composite Weight } \\
\hline & & Alt. 1 & Alt. 2 & Alt. 3 & Alt. 1 & Alt. 2 & Alt. 3 \\
\hline Material & 0,1137 & 0,1018 & 0,4828 & 0,4154 & 0,0116 & 0,0549 & 0,0473 \\
\hline Desain & 0,1641 & 0,0929 & 0,6684 & 0,2387 & 0,0152 & 0,1097 & 0,0392 \\
\hline Alat Penyangga & 0,4204 & 0,1091 & 0,5765 & 0,3143 & 0,0459 & 0,2424 & 0,1322 \\
\hline Fitur Tambahan & 0,3017 & 0,0773 & 0,7138 & 0,2089 & 0,0233 & 0,2154 & 0,0630 \\
\hline & Total & & & & 0,0960 & 0,6224 & 0,2816 \\
\hline
\end{tabular}

Tabel 14. Dimensi dan Gambar Meja Perakitan Controller

\begin{tabular}{|c|c|c|c|c|c|c|c|}
\hline No. & Dimensi & Fungsi & Persentil & $\begin{array}{c}\text { Ukuran } \\
(\mathrm{mm})\end{array}$ & $\begin{array}{c}\text { Penyesuaian } \\
\text { (mm) }\end{array}$ & $\begin{array}{l}\text { Total } \\
(\mathrm{mm})\end{array}$ & Gambar \\
\hline 1. & $\begin{array}{l}\text { Jarak Bentang dari } \\
\text { Ujung Jari Tangan } \\
\text { Kiri ke Kanan }\end{array}$ & $\begin{array}{c}\text { Panjang } \\
\text { Meja }\end{array}$ & $5 \%$ & 1520 & $\begin{array}{c}20 \% \\
(-300 \\
\mathrm{mm})\end{array}$ & 1220 & \\
\hline 2. & $\begin{array}{l}\text { Jarak dari Siku ke } \\
\text { Ujung Jari }\end{array}$ & $\begin{array}{l}\text { Lebar } \\
\text { Meja }\end{array}$ & $5 \%$ & 649 & $\begin{array}{c}7 \% \\
(-49 \mathrm{~mm})\end{array}$ & 600 & \\
\hline 3. & Diameter Controller & $\begin{array}{l}\text { Meja } \\
\text { Putar }\end{array}$ & - & 550 & $\begin{array}{c}5 \% \\
(30 \mathrm{~mm})\end{array}$ & 580 & \\
\hline 4. & Tinggi Bahu & $\begin{array}{l}\text { Tinggi } \\
\text { Rak dari } \\
\text { Lantai }\end{array}$ & $5 \%$ & 1247 & - & 1247 & \\
\hline 5. & $\begin{array}{lr}\text { Tinggi } & \text { Pegangan } \\
\text { Tangan } & \text { (grip) pada } \\
\text { Posisi } & \text { Tangan } \\
\text { Vertical ke } & \text { Atas \& } \\
\text { Berdiri } & \end{array}$ & $\begin{array}{l}\text { Tinggi } \\
\text { Perkakas } \\
\text { di } \\
\text { Gantung }\end{array}$ & $5 \%$ & 1795 & - & 1795 & \\
\hline 6. & Tinggi Siku & $\begin{array}{l}\text { Tinggi } \\
\text { Meja }\end{array}$ & $5 \%$ & 932 & - & 932 & \\
\hline
\end{tabular}

Setelah dirancang meja dengan ukuran yang ergonomis maka dilakukan simulasi yang dilakukan dengan menggunakam menggunakan software CATIA untuk menghitung REBA hasil konsep setelah penerapan. Untuk kegiatan yang akan dihitung adalah kegiatan proses perakitan controller dan kegiatan menjangkau, yang mana pada kedua kegiatan tersebut memiliki perubahan postur tangan yang signifikan. Berikut merupakan tabel rekapitulasi REBA pada kegiatan perakitan dan jangkauan dapat dilihat pada Tabel 15.

\section{IMPLEMENTASI PRODUK}

Berdasarkan konsep perancangan yang terpilih sebelumnya, maka dibuat rancangan sesuai dengan ukuran sesungguhnya sehingga dapat diimplementasikan langsung untuk mengetahui kegiatan pekerja perakitan di PT. Multitanaka Suryatama dalam menggunakan 
rancangan perbaikan. Gambar hasil perancangan dapat dilihat pada Tabel 16.

Dari proses implementasi dilakukan penelitian dengan peta tangan kanan dan tangan kiri, yang mana didapatkan perubahan waktu baku yang cukup signifikan. Pengurangan waktu kerja disebabkan adanya eliminasi kegiatan seperti kegiatan mencari dan memilih benda kerja. Selain itu pada implementasi terdapat tempat untuk meletakkan komponen dan perkakas menurut jenisnya masing-masing, juga terdapat tempat untuk meletakkan kabel. Itu semua diletakkan dengan rapi maka tidak ada kegiatan mencari dan memilih sehingga mengurangi waktu kerja. Implementasi fasilitas kerja dilakukan selama 10 hari. Fasilitas kerja digunakan oleh satu orang operator. Sebelum dan setelah dilakukan implementasi pekerja diminta untuk mengisi kuisioner NBM (Nordic Body Map) untuk membandingkan keluhan fisik yang dialami pekerja sebelum dan setelah melakukan implementasi. Dimana keluhan fisik yang dirasakan berkurang dari 15 bagian tubuh menjadi 2 bagian tubuh, yaitu pada leher dan betis kanan. Walaupun masih ada keluhan dari pekerja namun jumlah keluhan fisik tersebut sudah berkurang dari kondisi awal. Maka dapat disimpulkan bahwa fasilitas kerja berupa meja yang dirancang dapat menurunkan keluhan fisik para pekerja di PT. Multitanaka Suryatama. Tahap selanjutnya adalah melakukan analisis hasil implementasi dari fasilitas kerja yang baru dengan menggunakan Rapid Entire Body Assessment (REBA) pada 6 postur tubuh operator yang akan dianalisis. Dengan begitu didapatkan tabel perbandingan sebelum dan sesudah implementasi dari hasil analisis Nordic Body Map (NMD) dan Rapid Entire Body Assessment (REBA) yang dapat dilihat pada Tabel 17.

Tabel 15. Tabel Rekapitulasi REBA Pada Kegiatan Perakitan dan Jangkauan

\begin{tabular}{ccccc}
\hline Kegiatan & Gambar Postur Pekerja & $\begin{array}{c}\text { Skor } \\
\text { Reba }\end{array}$ & $\begin{array}{c}\text { Level } \\
\text { Resiko }\end{array}$ & $\begin{array}{c}\text { Tindakan } \\
\text { Perbaikan }\end{array}$ \\
\hline $\begin{array}{c}\text { Melakukan } \\
\text { Perakitan }\end{array}$ & 3 & Rendah & $\begin{array}{c}\text { Mungkin } \\
\text { Diperlukan }\end{array}$ \\
$\begin{array}{c}\text { Melakukan } \\
\text { Jangkauan }\end{array}$ & 3 & Rendah & $\begin{array}{c}\text { Mungkin } \\
\text { Diperlukan }\end{array}$ \\
& & & & \\
\end{tabular}

Tabel 16. Gambar Hasil Perancangan

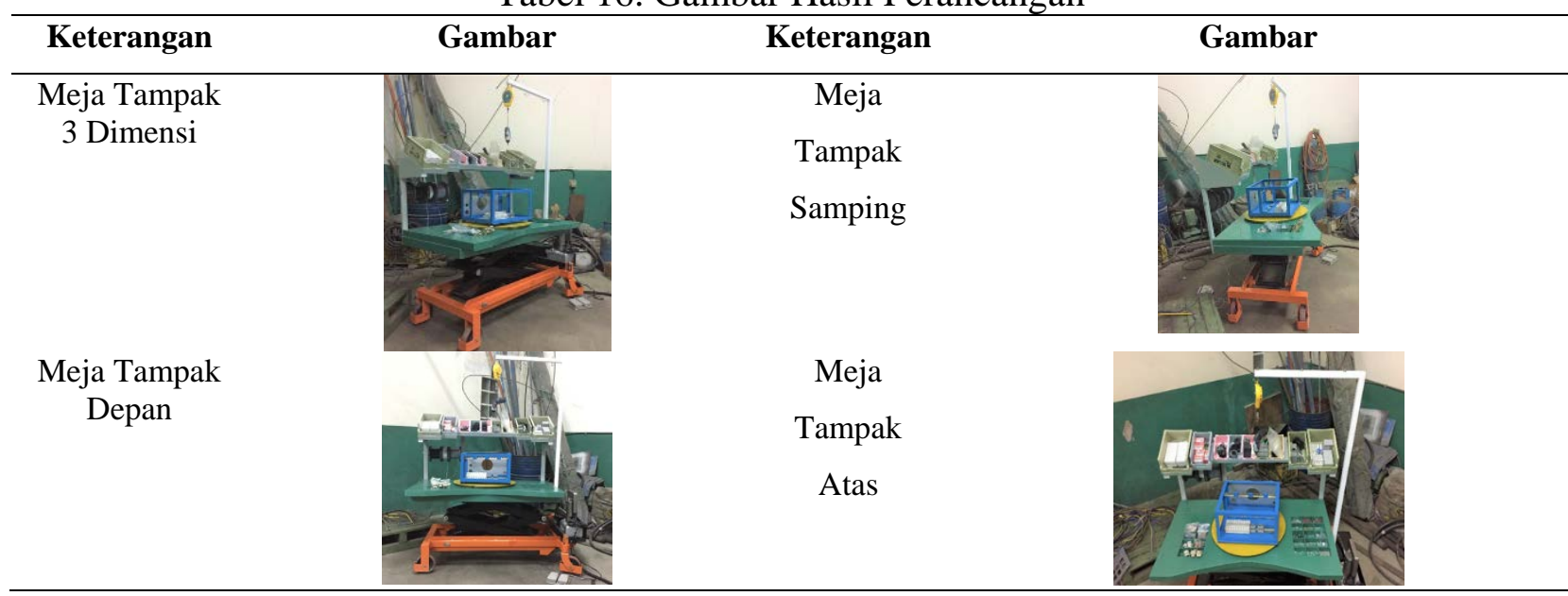


Tabel 17. Tabel Perbandingan Sebelum dan Sesudah Implementasi

\begin{tabular}{|c|c|c|c|c|c|}
\hline \multicolumn{2}{|c|}{ Metode } & \multicolumn{2}{|c|}{ Sebelum Implementasi } & \multicolumn{2}{|c|}{ Sesudah Implementasi } \\
\hline \multicolumn{2}{|c|}{ Nordic Body Map (NBM) } & \multicolumn{2}{|c|}{$\begin{array}{c}\text { Pinggang bawah, leher atas, } \\
\text { pinggang, punggung, betis kanan, } \\
\text { telapak kaki kiri, pantat, betis kiri, } \\
\text { telapak kaki kanan, bahu kanan, } \\
\text { bahu kanan, pergelangan tangan } \\
\text { kanan, tangan kanan, lengan atas } \\
\text { kanan, leher bawah, bahu kiri, } \\
\text { lengan atas kiri, lengan bawah } \\
\text { kanan. }\end{array}$} & \multicolumn{2}{|c|}{ Leher atas dan betis kanan. } \\
\hline \multirow{7}{*}{$\begin{array}{l}\text { Rapid Entire } \\
\text { Body } \\
\text { Assessment } \\
\text { (REBA) }\end{array}$} & Kegiatan & Skor REBA & Level Resiko & Skor REBA & Level Resiko \\
\hline & Memotong Kabel & 5 & Sedang & 2 & Rendah \\
\hline & $\begin{array}{c}\text { Mengencangkan } \\
\text { Baut }\end{array}$ & 10 & Tinggi & 2 & Rendah \\
\hline & $\begin{array}{c}\text { Memasukkan } \\
\text { Kabel ke }\end{array}$ & 9 & Tinggi & 2 & Rendah \\
\hline & $\begin{array}{c}\text { Konektor } \\
\text { Merapihkan } \\
\text { Kabel }\end{array}$ & 9 & Tinggi & 2 & Rendah \\
\hline & Memasang Fan & 11 & Sangat Tinggi & 2 & Rendah \\
\hline & $\begin{array}{l}\text { Melakukan } \\
\text { Jangkauan }\end{array}$ & 10 & Tinggi & 2 & Rendah \\
\hline
\end{tabular}

Kemudian juga dilakukan analisis waktu untuk mengetahui waktu siklus bekerja dengan melakukan perhitungan waktu kerja mulai dari tanggal 4 Desember sampai 14 Desember sehingga didapatkan 7 data perakitan. Tetapi terlebih dahulu membuktikan data normal, seragam dan jumlah cukup, maka setelah itu didapatkan waktu siklus selama 10,5 jam/produk.

\section{KESIMPULAN}

Pada proses perakitan controller terdapat risiko musculoskeletal yang juga mempunyai 17 jenis keluhan fisik para pekerja. Yang kemudian dianalisis REBA dari 5 kegiatan, dimana terdapat level resiko pada skor REBA tertinggi pada saat melakukan memasang komponen fan pada controller yaitu 11 dan diperlukannya tindakan perbaikan segera. Selain untuk mengurangi tingkat risiko musculoskeletal, penelitian ini juga bertujuan untuk mengurangi waktu baku dan mendapatkan sistem kerja terbaik. Maka dilakukan analisis dengan menggunakan peta tangan kanan dan tangan kiri pada 11 pekerjaan dalam melakukan proses perakitan controller agar pekerjaan yang tidak efisien dapat diidentifikasi dan diperbaiki. Dimana didapatkan kegiatan mencari dan menganggur yang cukup lama dan waktu siklus terlama adalah pada pekerjaan pemasangan schon yaitu 381 detik. Untuk proses perakitan didapatkan waktu baku perakitan untuk satu controller yaitu 15,69 jam. Kemudian dilakukan proses perancanagan, penyusunan dan pemilihan konsep dilakukan untuk proses perakitan controller yang terpilih satu buah alternatif desain yaitu alternatif 2. Pengujian untuk melakukan uji REBA pada alternatif 2 dilakukan dengan menggunakan software CATIA, dimana didapatkan shsil REBA yang sama sebesar 3 untuk proses perakitan dan proses penjangkauan. Sehingga perancangan fasilitas kerja alternatif dua dapat mengurangi tingkat risiko musculoskeletal. Setelah mengimplementasikan fasilitas kerja selama 10 hari, didapatkan identifikasi keluhan rasa sakit berkurang 14 keluhan fisik menjadi 2 keluhan fisik yaitu keluhan agak sakit leher atas dan agak sakit betis kanan. 6. Hasil penilaian REBA setelah implementasi fasilitas kerja menunjukkan terjadinya perbaikan postur pekerja dan penurunan tingkat risiko untuk proses perakitan controller. Setelah menggunakan alat bantu kerja yang baru, postur kerja pada proses perakitan controller untuk kegiatan memotong, kegiaan mengencangkan baut, kegiatan memasukkan kabel ke konektor, kegiatan merapihkan kabel dan kegiatan 
memasang fan memiliki masing-masing skor REBA 2, kemudian pada kegiatan jangkauan atas dan bawah memiliki skor REBA 2. Yang dapat disimpulkan secara garis besar bahwa penambahan dengan menggunakan meja kerja memiliki level resiko rendah. Fasilitas kerja yang baru juga terbukti dapat mengurangi waktu siklus untuk perakitan controller di PT. Multitanaka Suryatama yaitu dari 12.27 jam menjadi selama 10,5 jam atau sebesar $14.43 \%$.

\section{DAFTAR PUSTAKA}

[1] B. P. Maharani, B. Aribowo and N. Nurhasanah (2015), "Usulan Perbaikan Postur Kerja Karyawan CV Atham Toy's Mainan Kayu (ATMK) dengan Metode Quick Exposure Check," Jurnal PASTI, vol. IX, no. 3.

[2] R. N. Jalajuwita and I. Paskarini (2015), "Hubungan Posisi Kerja dengan Keluhan Muskuloskeletal pada Unit Pengelasan PT.X Bekasi," The Indonesian Journal of Occupational Safety and Health, vol. 4, no. 1

[3] N. R. As'ad, E. Achiraeniwati and Y. S. Rejeki (2016), "Perbaikan Sistem Kerja pada Industri Rumah Tangga Sepatu di Cibaduyut Bandung untuk Meminimasi Beban Kerja Mental," Jurnal Penelitian dan Pengabdian Masyarakat, vol. 4, no. 2.

[4] A. Kristanto and D. A. Saputra (2011), "Perancangan Meja dan Kursi Kerja yang Ergonomis pada Stasiun Kerja Pemotongan Sebagai Upaya Peningkatan Produktivitas," Jurnal Ilmiah Teknik Industri, vol. 10.

[5] A. Descantha, Y. Roquelaure, J.-F. Chastang, B. Evanoff, M. Melchior, C. Mariot, C. Ha, E. Imbernon, M. Goldberg and G. Leclerc (2007), "Validity of Nordic-style Quiistionnaire in the Suvrveillance of Upper-Limb WorkRelated Musculoskeletal Disorders," Scandinavian Jounral of Work, Environment \& Health.

[6] S. Hignett and L. McAtamney (2000), "Technical note Rapid Entire Body Assesment," Applied Ergonomics, vol. 1, no. 31.

[7] S. and O. M. Firdaus (2011), "Analisis Pengukuran RULA dan REBA Petugas pada Pengangkatan Barang di Gudang dengan Menggunakan Software Egro Intelligence (Studi kasus: Petugas Pembawa Barang di Toko Dewi Bandung)," in Prosiding Seminar Nasional Ritektra.

[8] N. Stanton, A. Hedge, K. Brookhuis, E. Salas and H. Hendrick (2005), Handbook of Human Factors and Ergonomics Methods, Washington, D.C.: CRC Press LLC.

[9] I. Z. Sutalaksana, R. Anggawisastra and J. H. Tjakraatmadja (2006), Teknik Perancangan Sistem Kerja, Bandung: Institut Teknologi Bandung.

[10] T. Rachman (2013), "Penggunaan Metode Work Sampling untuk Menghitung Waktu Baku dan Kapasitas Produksi Karungan Soap Chip di PT. SA," Jurnal Inovisi, vol. 9, no. 1.

[11] R. A. Simanjuntak and D. Hernita (2013), "Usulan Perbaikan Metode Kerja Berdasarkan Micromotion Study dan Penerapan Metode 5S untuk Meningkatkan Produktivitas," Institut Sains \& Teknologi AKPRIND, Yogyakarta.

[12] Y. Helianty, C. SW and M. L. Astuti (208), "Usulan Perbaikan Stasiun Kerja di Bagian Packing dengan Menggunakan PrinsipPrinsip Ergonomi (Studi Kasus di PT. Nikkatsu Electric Work)," Jurusan Teknik dan Manajemen Industri Institut Teknologi Nasional, Bandung.

[13] T. L. Saaty (2008), "Decision Making with the Analytic Hierarchy Process," Int. J. Services Science, vol. 1, no. 1.

[14] E. M. Pribadi, R. Wahyuniardi and A. Herquitanto (2009), "Analisis SIkap Kerja Statis Operator Bagian Maintenance \& Assembly PT. NTP-Bandung," in Prosiding Seminar Nasional Ergonomi IX, Semarang. 